\title{
APP-021 Replication of Prostate Cancer Risk Loci in a Japanese Case-control Association Study
}

\author{
東京慈恵会医科大学泌尿器科 ${ }^{1}$, 熊本大学大学院医学薬学研究部環境生命科学講座公衆衛生・医療科学 ${ }^{2}$, 東京慈恵

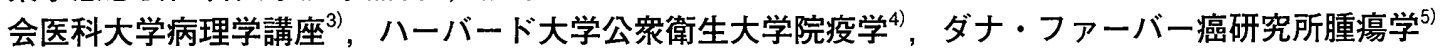 \\ 山田 裕紀 ${ }^{1)}$, 加藤 貴彦 ${ }^{2)}$, 鷹橋 浩幸 ${ }^{3)}$ ，キャサリン ペニー ${ }^{4\rangle}$, マシュー フリードマン ${ }^{5)}$, 車 英俊 ${ }^{1)}$, \\ 鎌田 裕子 ${ }^{12}$, 木村 高弘 ${ }^{1}$, 頴川 晋 ${ }^{11}$

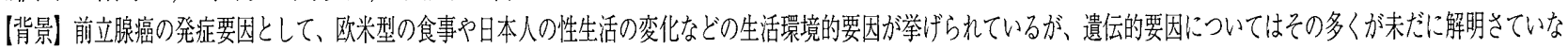

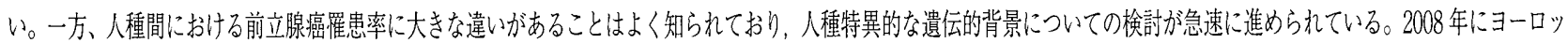

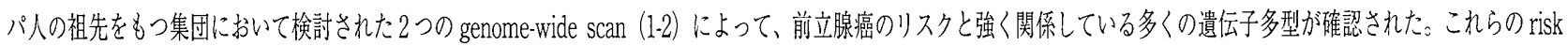

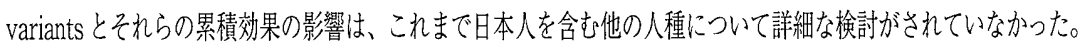

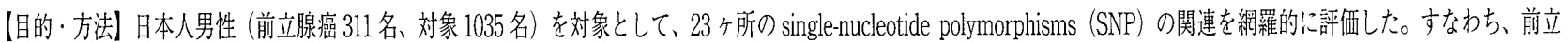

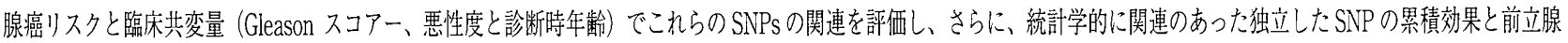

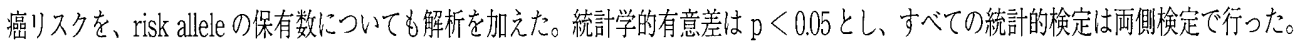

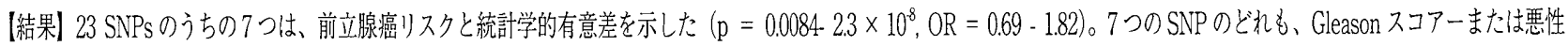

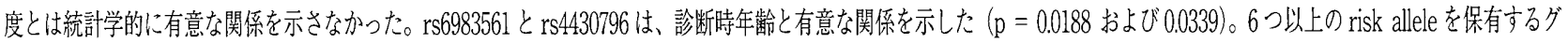

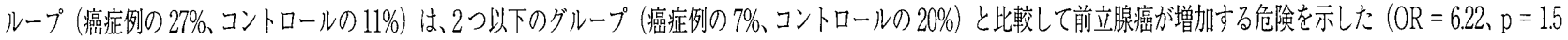

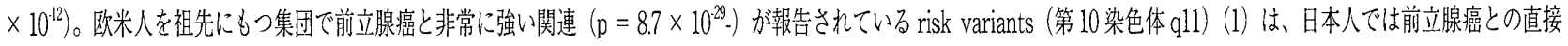 \\ の)関連加認好方れな加た $(\mathrm{p}=0.7241)(3)$ 。

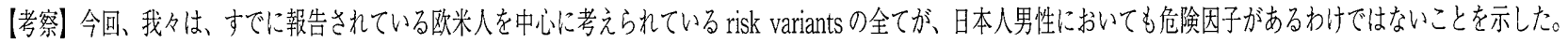

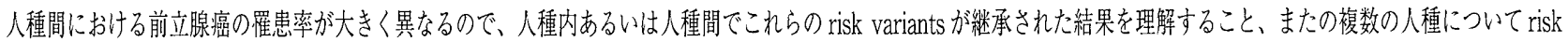 \\ variantsの影锌を理解することはきわめて重要である。本研究の結果は，risk variantsがどのよう集団全体て疾患に影響するか理解する際に、祖先を考慮することの重要性

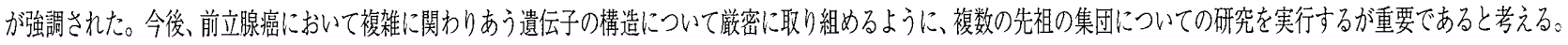 \\ (1) Nat Genet. 2008:40 (3) : 316-21. \\ (2) Nat Genet. 2008;40 (3) : 310-5. \\ (3) J Natl Cancer Inst 2009;101: 1.7
}

\section{APP-022 前立腺癌術前 PSA kinetics と全摘標本の病理組織学的結果の検討一術前 PSA Kinetics は癌容積・ Gleason score と相関しない一}

\section{久留米大学医学部泌尿器科学1), 久留米大学医学部病理学 ${ }^{2)}$, 久留米大学先端癌治療研究センター ${ }^{3)}$ \\ 野口 正典 ${ }^{13}$ ，末金 茂高 ${ }^{1)}$ ，守屋 普久子 ${ }^{1,2)}$ ，中島 収 ${ }^{2)}$ ，松岡 啓 ${ }^{11}$}

目 的 : PSA velocity (PSAV) やPSA doubling time (PSADT) を用いたPSA kinetics の測定は、前立腺癌治療 後の経過観察において重要視されている。しかしながら、未治療前立腺癌の治療前 PSA kineticsが治療法選択にお いて有用であるか議論の多いところである。そこで、術前 PSA kinetics と全摘標本の病理組織学的結果との相関を 検討した。対象と方法：術直前ならびに術前 3 ケ月から 1 年以内に 2 回以上の PSA 測定がなされ初回治療として根 治的前立腺全摘術が施行された 141 例を対象とした。摘出標本は、3 mm 幅の全割標本を作製し、癌容積、Gleason score、被膜浸潤の有無、断端陽性の有無、精囊浸潤の有無を評洒し、術前PSA、PSAV、PSADTとの関係をピア ソンの相関係数、ロジスティック回帰分析にて検討した。結 果 : 対象症例の年齢中央值は 68 歳 (47-78 歳)、術前 の臨床病期は Tlc 74 例、T2a 40 例、T2b 13 例、T2c 14 例であった。全摘標本の病理結果は、癌容積 $4 \mathrm{cc}$ 以上 34 例 $(24 \%) 、$ Gleason score 7 以上 95 例 (67\%)、被膜浸潤有り 26 例（18\%）、断端陽性 56 例 (40\%)、精囊浸潤有り 9 例 $(6.3 \%)$ でリンパ節転移を 1 例に認めた。術前のPSAの中央値は $7.7 \mathrm{ng} / \mathrm{ml}(2.1-76.8 \mathrm{ng} / \mathrm{ml}) 、 P S A V$ の央 值は $0.8 \mathrm{ng} / \mathrm{ml} /$ year (-36.6 - $107 \mathrm{ng} / \mathrm{ml} /$ year)、PSADT は 9.5 ケ月（-1354.8 - 1861 ケ月）であった。癌容積と術前 PSA、PSAV、PSADT の相関係数は、各々 $0.343(\mathrm{p}=0.001) 、 0.077 、-0.136$ と癌容積、術前 PSA 間に弱い相関を認 めた。Gleason score と術前PSA、PSAV、PSADT の相関係数は、各々 $0.031 、-0.088 、-0.046$ といずれも相関を認 めなかった。ロジスティック回帰にて癌容積 $4 \mathrm{cc}$ 以上、Gleason score 7 以上、被膜浸潤、断端陽性、精囊浸潤の各 項目を術前 PSA（10 ng/ml 以上)、PSAV（2.0 ng/ml/year 以上)、PSADT（12 ヶ月以上）の各因子で予知可能か解 析してみると、癌容積 $4 \mathrm{cc}$ 以上の項目においてのみ術前 PSA $10 \mathrm{ng} / \mathrm{ml}$ 以上が予知可能（オッズ比 $9.353 、 \mathrm{p}=0.001 ）$ で術前PSAVならびにPSADTはいずれの項目も予知できなかった。結 語：術前PSA kineticsは、PSA 測定単独 以上の前立腺癌悪性度を評価するのは困難であり未治療前立腺癌治療法選択に有用とはいえず、今後、PSA 以外の 有用なバイオマーカーの開発が望まれる。 